\title{
IMMUNE FUNCTION OF ZHENQI FUZHENG CAPSULE ON VOLLEYBALL PLAYERS AFTER HIGH INTENSITY TRAINING
}

\author{
FUNÇÃO IMUNITÁRIA DA CÁPSULA ZHENQI FUZHENG EM JOGADORES DE VOLEIBOL APÓS \\ TREINAMENTO DEALTA INTENSIDADE \\ EFECTO DE LA CÁPSULA ZHENQI FUZHENG SOBRE LA FUNCIÓN INMUNE DE LOS JUGADORES DE \\ VOLEIBOL DESPUÉS DEL ENTRENAMIENTO DEALTA INTENSIDAD
}

\author{
Lili Wang $^{1}$ (D) \\ (Public Health Education) \\ Hongfei Wang ${ }^{2}$ (DD \\ (Public Sports) \\ Wanliang Tuo ${ }^{3}$ \\ (Public Health Education)
}

1. Institute of Physical Education, Shihezi University, Shihezi 832003, Xinjiang, China.

2. Medical College, Shihezi

University, Shihezi 832003, Xinjiang, China.

3. Guilin Tourism University, Guilin

541006, Guangxi, China.

\section{Corespondence:}

Shihezi 832003, Xinjiang.

jjmrzo@163.com.

\begin{abstract}
At present, many studies have proved that proper exercise can promote the immune function of human body to a certain extent, but athletes need a lot of high-intensity sports training, and their immune function declines instead of improving. In order to control the decline of immune function of athletes after high-intensity training, this study propose the Zhenqi Fuzheng capsule to achieve this goal. Through experimental comparison, the parameters such as white blood cell content, immunoglobulin number, T lymphocyte, human hemoglobin content and exercise exhaustion time were detected after high-intensity training. The results showed that compared with the control group taking Zhenqi Fuzheng, the weight of those who had taken qifuzhengs capsule did not change, and the content of white blood cells, immunoglobulin, hemoglobin content and exercise time increased to a certain extent. The results showed that Zhenqi Fuzheng could inhibit the decrease of body immune function after high-intensity exercise, then accelerate the recovery of human immune function. This study is expected to enhance the immunity of sports athletes, and reduce athletes' pain after high-intensity training.
\end{abstract}

Keywords: Immunity; Exercise; Athletes.

\section{RESUMO}

Atualmente, muitos estudos prova que exercícios adequados podem promover a função imunológica do corpo humano em certa medida, mas os atletas precisam de muito treinamento esportivo de alta intensidade, e sua função imunológica diminui em vez de melhorar. A fim de controlar o declínio da função imunológica dos atletas após treinamento de alta intensidade, este estudo propôs a administração da cápsula Zhenqi Fuzheng para alcançar esse objetivo. Através de comparação experimental, foram detectados parâmetros como o teor de glóbulos brancos, imunoglobulina, linfócitos T, hemoglobina humana e tempo de exaustão do exercício após treinamento de alta intensidade. Os resultados mostraram que, em comparação com o grupo controle que tomou a cápsula Zhenqi Fuzheng, o peso daqueles que tinham tomado a cápsula de qifuzheng não se alterou, e o teor de glóbulos brancos, imunoglobulina, hemoglobina e o tempo de exercício aumentaram em certa medida. Os resultados mostraram que a cápsula Zhenqi Fuzheng poderia inibir a diminuição da função imunológica corporal após exercícios de alta intensidade, e acelerar a recuperação da função imunológica humana. Espera-se que este estudo possa aumentar a imunidade dos atletas e reduzir a dor dos atletas após treinamento alta intensidade para fornecer uma certa referência.

Descritores: Imunidade; Exercício; Atletas.

\section{RESUMEN}

Actualmente, muchos estudios prueban que ejercicios adecuados pueden promover la función inmunológica del cuerpo humano en cierta medida, pero los atletas precisan mucho entrenamiento deportivo de alta intensidad, y su función inmunológica disminuye en vez de mejorar. A fin de controlar la declinación de la función inmunológica de los atletas después del entrenamiento de alta intensidad, este estudio propuso la administración de la cápsula Zhenqi Fuzheng para alcanzar ese objetivo. Por medio de comparación experimental, fueron detectados parámetros como el tenor de glóbulos blancos, inmunoglobulina, linfocitos T, hemoglobina humana y tiempo de agotamiento del ejercicio después de entrenamiento de alta intensidad. Los resultados mostraron que, en comparación con el grupo control que tomó la cápsula Zhenqi Fuzheng, el peso de aquellos que habían tomado la cápsula de qifuzheng no se alteró, y el tenor de glóbulos blancos, inmunoglobulina, hemoglobina y el tiempo de ejercicio aumentaron en cierta medida. Los resultados mostraron que la cápsula Zhenqi Fuzheng podría inhibir la disminución de la función inmunológica corporal después de ejercicios de alta intensidad, y acelerar la recuperación de la función inmunológica humana. Se espera que este estudio pueda aumentar la inmunidad de los atletas y reducir el dolor después de entrenamiento de al ta intensidad para proveer una cierta referencia.

Descriptores: Inmunidad; Ejercicio; Atletas. 


\section{INTRODUCTION}

In sports events, in order to get better results, athletes often carry out a lot of high-intensity sports training to strengthen their physical fitness. Some professional athletes and ordinary people have a misunderstanding about physical exercise. People generally think that the ability of human body to resist virus will increase with the increase of exercise intensity, but this is actually a wrong cognition. In fact, the resistance of human body to virus depends on the immune system. The immune system of human body includes the production of special functional proteins and cell proliferation. Its mechanism can be divided into interference with the production of body fluids, antibody production, changes in cellular immune capacity, changes in phagocytic capacity and T cell proliferation response to mitogen. At present, many studies have proved that high-intensity sports training will affect athletes'immune ability to a certain extent, which makes athletes vulnerable to virus infection, especially upper respiratory tract virus infection and some common viral infections, such as gastroenteritis, malaria, and viral hepatitis. High intensity sports training will reduce the activity of T lymphocytes in the human body, and then show the decline of immunity. In this case, the ability of monitoring and killing virus invasion will be reduced to a certain extent. Finally, the virus will lurk in the human body, laying a hidden danger for the outbreak of disease. In order to reduce the decline of immunity ability of athletes after high-intensity sports training, this study proposed that Zhenqi Fuzheng Capsule should be supplemented during exercise, so as to control the decline of human immunity and recover quickly after the decline of immunity. ${ }^{1}$

In order to study the effect of Zhenqi Fuzheng Capsule on immune ability after high-intensity training, the pharmacology of Zhenqi Fuzheng Capsule was analyzed firstly, and then the influence of high-intensity training on human immune ability was elaborated. This study used the method of comparative experiment, the participants were divided into groups, and the body indicators were detected. Finally, the influence of qifuzheng Capsule on the immune ability after high-intensity training was analyzed through the differences of body indexes of experimental personnel in each group. We hope that through this study, we can reduce the body immunity decline or virus infection caused by high intensity training. ${ }^{2}$

In this study, the parameters of human leukocyte content, immunoglobulin quantity, T lymphocyte, NK cell content, hemoglobin content and exhaustion time of high intensity training were used to represent the immune capacity of human body, and this series of parameters in human body were detected and compared by comparative experiment. This method can objectively and directly express the level of human immune ability, and then directly reflect the influence of Zhenqi Fuzheng Capsule on the immune ability after high-intensity training.

This study mainly consists of four parts. The first part mainly describes the domestic and foreign scholars' research on the changes of human immune capacity after high-intensity training. ${ }^{3}$ The second part mainly describes the pharmacological analysis of Zhenqi Fuzheng Capsule and the influence of high-intensity training on human immune system. The third part mainly describes the method of experimental comparison to design an experiment that can reflect the effect of Zhenqi Fuzheng Capsule on human immune function after high-intensity training, and it is proved by examples. The fourth part mainly analyzes the influence of qifuzheng Capsule on the parameters of human immune system, as well as some deficiencies in this study.

\section{RELATED WORK}

To a certain extent, the immune ability of a sports athlete determines the quality of the athlete's sports performance and the length of his sports career. Therefore, the research on human immune ability has become a hot spot of current research. Haase $h$ and other researchers proposed to study zinc signal and transform it into a sensor for biochemical events. Through this research, people can have a deeper understanding of the role of zinc in immune cells. ${ }^{4}$ Klein s I et al. Proposed that the antibody responses of male and female infants after vaccination were not the same, and the effects of different vaccines such as BCG, measles, mumps and rubella vaccine, yellow fever virus on infants and elderly individuals were studied. The results show that women usually have higher antibody response and more adverse reactions than men after vaccination. ${ }^{5}$ Bobrove a $\mathrm{m}$ et al. Proposed the quantitative determination of $\mathrm{T}$ and $\mathrm{B}$ lymphocytes in peripheral blood of untreated patients with Hodgkin's disease, and compared with phytohemagglutinin (PHA) stimulation and delayed skin allergic reaction. The results show that T lymphocytes in peripheral blood generally do not decrease in untreated Hodgkin's disease.

\section{ANALYSIS AND DISCUSSION}

During the 5-week training in this study, various parameters of the participants were measured, and all the experimental data were in windows After data processing by Excel and SPSS15.0 software, the significant differences of each index between the experimental groups were tested by one-way ANOVA, and then expressed by the mean standard deviation, and the significance level was $a=0.05$.

Figure 1 shows the comparison chart of exhausting time of the experimental personnel participating in high-intensity training in this study. From the figure, we can see that there are significant differences between the quiet control group, the exercise control group, the quiet medication group and the exercise medication group ( $P<0.05)$. There was a significant difference between $Y G$ and $y d(P<0.01)$, and there was also a significant difference between $\mathrm{Ag}$ and yd $(P<0.01)$.

Figure 2 shows the comparison of leukocyte and its subpopulations in each group, including the comparison of leukocyte content, neutrophil content and lymphocyte content in human body. According to the white blood cell contrast chart of each group, it can be seen that the white blood cell content in the medication group is higher than that in the non medication experimental group, and there is a significant difference between the quiet control group (AD) and the quiet medication group ( $\mathrm{Ag})(P<0.05)$, while there is a very significant difference between the exercise medication group and the exercise control group $(P<0.01)$ It can be caused by the decline of immune function after 5 weeks of high-intensity training. In addition, this study also tested the immunoglobulin content of each group after high-intensity training, and the test results are shown in Table 1.

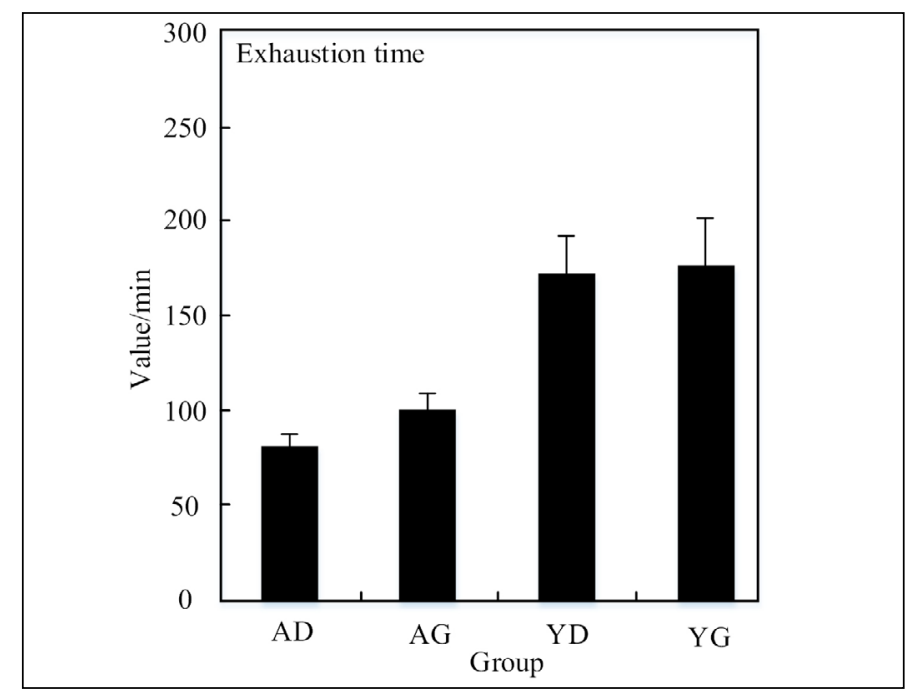

Figure 1. Exhaustion time of each group of experimental personnel in high-intensity training. 


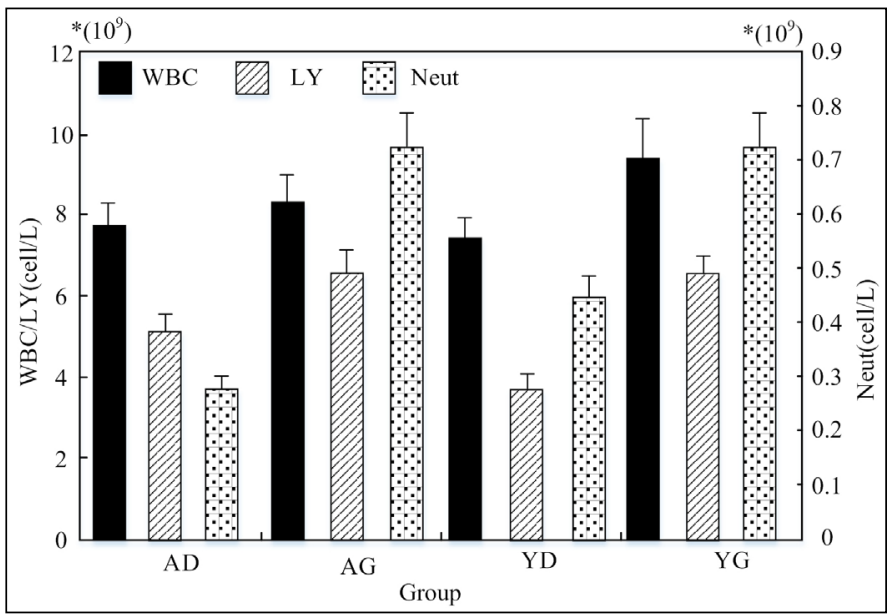

Figure 2. Comparison results of white blood cells and their subgroups of experimenters in each group.

Table 1. Comparison results of immunoglobulin content of experimenters in each group.

\begin{tabular}{ccccc}
\hline Parameter & AD & AG & YD & YG \\
$\lg A(g / L)$ & $0.56 \pm 0.06$ & $0.80 \pm 0.11$ & $0.31 \pm 0.12$ & $0.61 \pm 0.12$ \\
$\lg G(\mathrm{~g} / \mathrm{L})$ & $3.14 \pm 0.33$ & $3.29 \pm 0.52$ & $2.29 \pm 0.42$ & $3.15 \pm 0.46$ \\
$\lg M(\mathrm{~g} / \mathrm{L})$ & $0.49 \pm 0.02$ & $0.65 \pm 0.06$ & $0.33 \pm 0.07$ & $0.58 \pm 0.06$ \\
\hline
\end{tabular}

Table 1 shows the comparison results of immunoglobulin content of four groups of laboratory personnel in this study. Through comparison, it can be seen that the content of immunoglobulin in Ag group is the highest, while that of YD group is the lowest.

Figure 3 shows the comparison of immunoglobulin among the experimental personnel in each group. The figure includes the comparison of IgA, IgG and IgM contents in human body. Combined with table 1 and figure 3 , we can analyze the influence of high-intensity training on the immunoglobulin of experimental personnel. After 5 weeks of high-intensity training, it can be found that the IgA content in the experimental personnel is generally reduced, and the IgA content of the experimental personnel in the medication group is higher than that in the non medication group. After the comparison among the groups, it can be seen that the IgA content in the quiet medication group is the highest, and that in the exercise medication group is the second. There was a significant difference between the quiet control group (DA) and the quiet medication group $(\mathrm{Ag})(\mathrm{P}<0.01)$, and the IgA content between the exercise control group (YD) and the exercise medication group (YG) was very significant $(P<0.01)$. In conclusion, Zhenqi Fuzheng Capsule can effectively reduce the $\mathrm{gA}$ immunosuppressive effect of human body after high-intensity training, and then improve the immune capacity of the body. Similarly, through the comparison between table 1 and figure 3 , we can find the influence of high-intensity training on IgG and IgM. In the comparison of IgG content, there was a significant difference between the quiet control group (DA) and the quiet medication group (Ag) $(P<$ $0.05)$, while there was a very significant difference between the exercise control group (YD) and the exercise medication group $(\mathrm{Ag})(\mathrm{P}<0.01)$. In the study of IgM content, it can be seen that after high-intensity training, the IgM content in the body of the experimental personnel decreased to a certain extent, while the IgM content of the experimental personnel taking Zhengi Fuzheng Capsule was significantly higher than that of the experimental personnel who did not accept the drug $(P<0.05)$. Table 1 and figure 3 show that there is a significant difference between the quiet control group (AD) and the quiet medication group (Ag) $(P<0.05)$, while there is a very significant difference between the exercise control group and the exercise medication group $(P<0.01)$.
Figure 4 shows the comparison results of T-lymphocyte subsets and NK cells in each group. Through the comparison of T-lymphocyte subsets (CD4\% / CD8\%), the study found that there was a significant difference between the quiet control group (AD) and the quiet medication group $(\mathrm{Ag})(\mathrm{P}<0.05)$, and there was also a significant difference between the exercise control group (YD) and the quiet medication group (Ag) $(\mathrm{P}<$ 0.05). The NK cells of each group were compared. It can be seen from Figure 4 that there is a significant difference between the quiet control group (AD) and the quiet medication group (Ag) $(\mathrm{P}<0.05)$, and there is also a significant difference between the exercise control group (YD) and the exercise medication group (Ag) $(\mathrm{P}<0.05)$.

Figure 5 shows the comparison results of red blood cell (RBC) and hemoglobin (HB) of each group of experimental personnel after the experiment. Through the comparison of the experimental personnel in each group in Figure 5 , it can be found that there is a significant difference in RBC content between the quiet medication group ( $\mathrm{Ag}$ ) and the quiet control group (AD) $(P<0.05)$, and the $\mathrm{Hb}$ content between the quiet control group (AD) and the exercise medication group (YG) is also significantly different $(P<0.05)<0.05)$. There were significant differences in $\mathrm{RBC}$ and $\mathrm{Hb}$ content between the two groups without high intensity training.

To sum up, through the experiment, we can see that Zhenqi Fuzheng Capsule can improve the content of white blood cells and its subsets to a certain extent, and thus reduce the loss of immune function caused by high-intensity training. Secondly, Zhenqi Fuzheng Capsule can improve the quantity of immunoglobulin under normal conditions, and reduce the inhibition of immunoglobulin after intensive training. In addition,

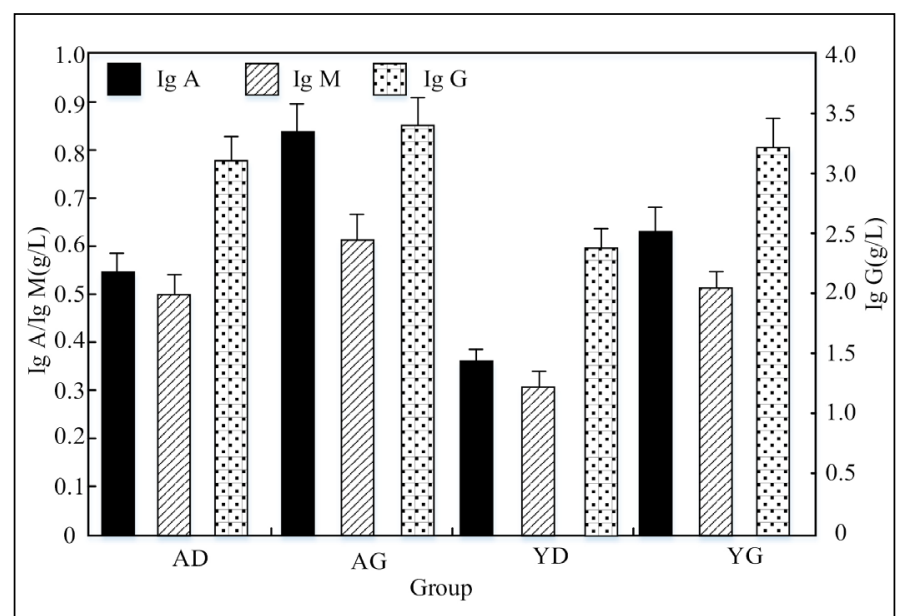

Figure 3. Comparison results of immunoglobulins of experimenters in each group.

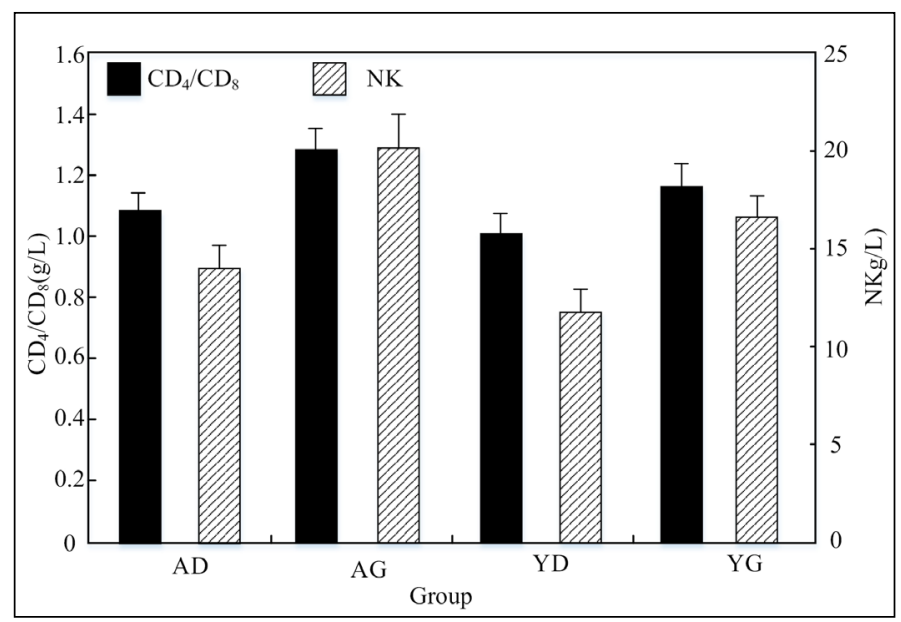

Figure 4. Comparison results of T lymphocyte subsets and NK cells of each group of experimenters. 


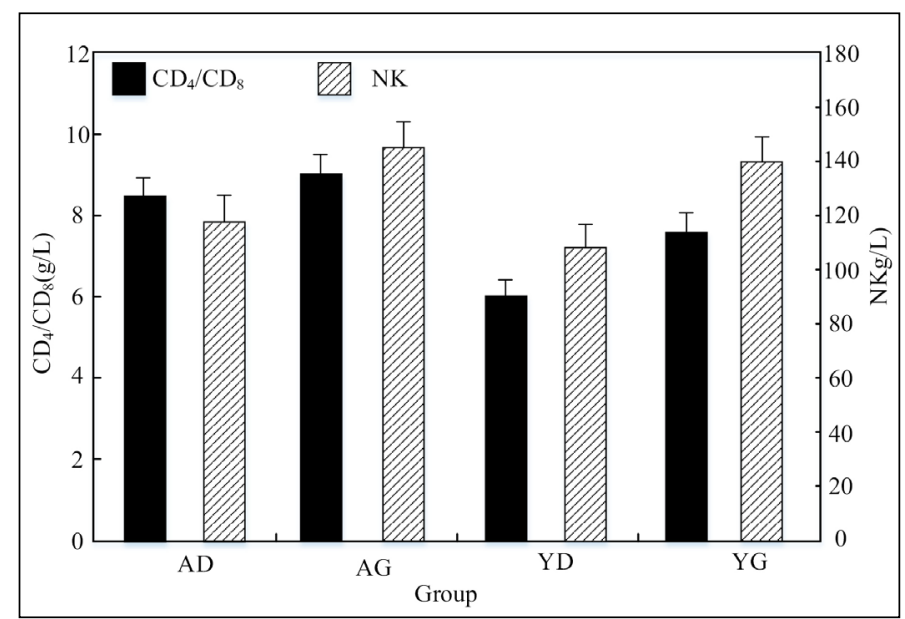

Figure 5. Comparison results of red blood cells and hemoglobin of experimenters in each group.

Zhenqi Fuzheng Capsule can also reduce the decrease of T lymphocyte and NK cell content after high-intensity training, which will lead to the decrease of human immunity, so as to enhance the immune ability of the body. The hemoglobin content of Zhenqi Fuzheng Capsule after high-intensity training is higher than that of the experimental personnel taking Zhenqi Fuzheng Capsule, which indicates that Zhenqi Fuzheng Capsule can improve aerobic exercise ability to a certain extent.

\section{CONCLUSION}

The decline of human immunity after high-intensity training is one of the main factors threatening the health of sports athletes. In order to control the situation and ensure the health of athletes, this study proposed taking Zhenqi Fuzheng Capsule, and analyzed the influence of Zhenqi Fuzheng Capsule on human immune function after high-intensity training. Through the analysis of the pharmacology of Zhenqi Fuzheng Capsule and the influence of high-intensity training on human immunity, this study detected a number of physical indicators of each experimental personnel in the way of comparative experiment, so as to explore the influence of Zhenqi Fuzheng Capsule on human immune function after high-intensity training. The results show that Zhenqi Fuzheng Capsule can effectively improve the content of white blood cells and immunoglobulin in human body, reduce the decline trend of T lymphocyte and NK cell content after high-intensity training, and then enhance the immune ability of human body. It is hoped that this study can provide some reference for improving the immunity ability of athletes. However, there are still some deficiencies in this study. The high-intensity training carried out by this research are all carried out by volleyball players, so the universality of this study needs to be further confirmed.

All authors declare no potential conflict of interest related to this article

\section{REFERENCES}

1. Xue L, Sun QM, Yu H, Liang YH, Li CS. Relationship between Cellular Immunity Changes and Prognosis in Elderly Patients with Sepsis. J Coll Physicians Surg Pak. 2019;29(12):1144-8.

2. Shlepotina NM, Peshikova MV, Kolesnikov OL, Shishkova YS. Modern conceptions about the mechanisms of interaction between biofilm and cellular immunity factors. Journal of Microbiology, Epidemiology and Immunobiology. 2020;97(1):83-90.
3. Lee AS, Jang SH, Kim BH, Shibata T, Yoo J, Jung Y, et al. Insecticidal activity of the metalloprotease AprA occurs through suppression of host cellular and humoral immunity. DCI. 2018;81:116-26.

4. Haase H, Rink L. Zinc signals and immune function. Biofactors. 2014;40(1):27-40.

5. Klein SL, Marriott I, Fish EN. Sex-based differences in immune function and responses to vaccination. Trans R Soc Trop Med Hyg. 2015;109(1):9-15. 